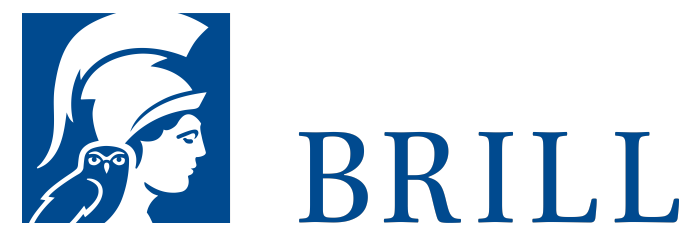

\title{
Mr. Spock und der malerische Doppelmord zu Königsleben
}

\author{
Author: Edgar Allan Wolfe
}

Im Kunsthistorischen Institut der Jean-Paul-Universität im thüringischen Königsleben (nahe Kaisersaschern) ereignen sich zwei mysteriöse Mordfälle, Giftmorde mit den >philosophischen< Toxinen Belladonna und Schierling. Die beiden Stardetektive Laurenz Silvester (Professor der Philosophie) und Mr. Spock (norwegischer Waldkater) bekannt geworden besonders durch ihre hier erneut abgedruckten, international beachteten Thesen zur Ästhetik des Detektivromans - kommen dank tatkräftiger Hilfe ihrer zweiund vierbeinigen Freunde den Übeltätern auf die Spur. Diese Detektivgeschichte zeigt augenzwinkernd auf die Verwandtschaft von Philosophieren und Detektivieren, blickt hinter die Kulissen des heutigen Universitätsbetriebs und berichtet über eine Weltsensation für die Kunstgeschichte: den Fund dreier Meisterwerke der Malerei, bislang unbekannter Gemälde von Hans Holbein dem Jüngeren, Marcel Duchamp und René Magritte - eine spannende Geschichte im Geiste von Dorothy Sayers, Edmund Crispin, Rex Stout und Martha Grimes, stets getreu dem Slogan: »Nicht alles für die Katz, sondern alles für die Katzen!«

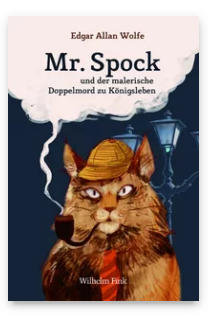

Pages: 153

Seiten

Language:

German

Subjects:

General, Philosophy

Publisher: Brill | Fink

E-Book (PDF)

Released online: 28 Apr 2020

ISBN: 978-38467-0016-7 List price 
Edgar Allan Wolfe, geb. 1965 in Frankfurt, Studium der Kunstund Literaturwissenschaft sowie der Philosophie in New York und Berlin; Lehrtätigkeit an verschiedenen deutschen Universitäten, seit 2001 freier Schriftsteller, Verfasser von Detektivromanen; lebt in Thüringen.

For more information see brill.com

Order information: Order online at brill.com +44330 333 o049 | customerservices@brill.com Submission information: brill.com/authors

Titles published by Brill | Fink, Brill | mentis or Brill | Schöningh: +49(o)71 5413279216 | brill@brocom.de 